СПЕЦИФИКА СУДОПРОИЗВОДСТВА С УЧАСТИЕМ ПРИСЯЖНЫХ ЗАСЕДАТЕЛЕЙ

Щенёва Дарья Владимировна

Студентка 3 курса Магистратуры Федерального государственного бюджетного образовательного учреждения высшего образования «ТАМБОВСКИЙ ГОСУДАРСТВЕННЫЙ ТЕХНИЧЕСКИЙ УНИВЕРСИТЕТ» (ФГБОУ ВО «ТГТУ»), 392000, Тамбовская область, г.Тамбов, ул.Советская, д.106

\title{
SPECIFICITY OF LEGAL PROCEEDINGS WITH THE PARTICIPATION OF LIABLE JOURNEYS
}

Scheneva Daria Vladimirovna 3rd year student of the Master Federal State Budgetary Educational Institution of Higher Education "TAMBOV STATE TECHNICAL UNIVERSITY" (FSBEI HE "TSTU"), 392000, Tambov Region, Tambov, Sovetskaya St., 106

\begin{abstract}
АННОТАЦИЯ
В статье характеризуется специфика судебного производства с участием присяжных заседателей, вопросы по формированию суда присяжных в свете требований российского законодательства.

\section{ABSTRACT}

The article characterizes the specifics of the trial with the participation of jurors, questions on the formation of a jury in the light of the requirements of Russian law.

Ключевые слова: суд присяжных, институт присяжных заседателей, коллегия присяжных, судопроизводство, уголовный процесс, федеральный закон.
\end{abstract}


Keywords: jury trial, jury institution, jury, legal proceedings, criminal procedure, federal law.

В процессе эволюционного развития суд присяжных претерпел множество преобразований.

Как считают историки еще в IX в., в «Русской правде» содержатся зачатки суда присяжных: п.14 «Если кто будет взыскивать с другого деньги, а тот станет отказываться, то идти ему на суд 12 человек» [8].

На всем протяжении своего развития данный институт присяжных перенес таких изменений, характер которых зависел от политического положения российского государства. У правоведов имеются различные точки зрения по вопросам возникновения суда присяжных в нашей стране. До настоящего времени нет единого мнения о том, сколько лет существует эта модель судебного производства.

Как констатирует доктрина уголовного судопроизводства, институт присяжных заседателей имеет свои своеобразные черты, что служит темой дебатов среди теоретиков и практических работников.

В юридической практике существуют мнения сторонников и противников суда присяжных заседателей. Противники указывают на неспособность присяжных качественно отправлять правосудие, что приводит к высокому проценту вынесения оправдательных вердиктов. Сторонники же утверждают, что суд присяжных заседателей ведет к повышению качества деятельности органов уголовного преследования и качества правосудия, и настаивают на выведении судов присяжных на уровень районных (городских) судов. По мнению, А.А. Ильюхова: «суд присяжных заседателей не нацелен на достижение объективной или формальной истины, а его решения во многом зависят от результативности приемов убеждения, используемых сторонами процесса» [3, с. 5-12]. В своих решениях они как раз и руководствуются здравым смыслом, жизненным опытом и совестью, которые позволяют им принимать порой нестандартные, рискованные, но обоснованные решения, в то 
время как профессиональные судьи скованы правовыми нормами, и на их решения влияние оказывают профессиональная деформация и косность мышления.

В настоящее время в России судопроизводство с участием присяжных заседателей реформируется. Принят Ф3 № 190-Ф3, предусматривающий расширение института суда присяжных заседателей, разрешил подозреваемым в неправомерных действиям против личности по уголовным делам «право ходатайствовать о рассмотрении их дел коллегией в составе судьи районного суда, гарнизонного военного суда и шести присяжных заседателей; снизил количество присяжных заседателей при рассмотрении уголовных дел в судах субъектов федерации и военных судах до восьми. Федеральный закон вступил в силу с 1 июня 2017 года, за исключением некоторых положений, вступающих в силу с 1 июня 2018 года» [7].

Для суда присяжных характерны такие признаки, как:

1. дифференциация компетенций судьи и состава присяжных заседателей;

2. индивидуальный метод избрания присяжных заседателей;

3. у присяжных заседателей нет юридического образования, не знают нормы материального и процессуального права, нет судейского опыта;

4. неоднородный состав коллегии присяжных заседателей;

5. до начала слушания в суде присяжные заседатели не информированы о предстоящем рассмотрении уголовного дела.

На основе отмеченных моментов, можно рассматривать такое понимание суда присяжных: это специфическая форма процесса судебного слушания, предназначенная для исследования и принятия решения по конкретному уголовному делу, специфическим составом суда (профессионалов и присяжных заседателей), у которых имеется личная убежденность касательно условий совершенного преступления в границах применения состязательности, а на решении основываться на совести и справедливости.

У населения сложилось такое мнение, что суд присяжных, это не только судьи-профессионалы, но и общественные представители. Можно сказать, что 
происходит сотрудничество как государственно-правовых, так и общественных начал, т.е. суд присяжных- парламентарии общества в области правосудия. Поэтому решения коллегии присяжных можно принимать как выдвинутые от имени общества в целом.

В реформировании современного суда проявляется углубленное осмысление и большое значение: увеличение прав данного института должно ориентировать на результат двух первостепенных задач: действительное предоставление права граждан на участие в осуществлении правосудия, согласно Основного закона РФ и усиление доверия общества к суду и качества правоприменения.

Институту присяжных заседателей отводится главенствующая роль, так как он способствует осуществлению правосудия на основе федерального законодательства. Тем более, сотрудничество в суде присяжных- гражданский долг. Говоря о роли присяжных заседателей, нельзя не сказать о том, что их участие -реализация принципа коллегиальности правосудия. Их деятельность в судебных органах показывает их демократичность, общественный контроль за обоснованностью, законностью и справедливостью работы судей.

Как отмечается в Конституции РФ, право гражданина на суд присяжных реализуется в рассмотрении уголовных дел судами различной категории общей юрисдикции. Хотя суду присяжных отнесены сорок шесть составов преступлений, относящихся к УК РФ, но практически слушается лишь некоторая часть.

Настоящим УПК РФ с 2018г. с участием районного судьи и коллегией из шести заседателей по обращению подозреваемого принимаются на слушания дела о таких преступлениях: убийство (ст. 105 ч. 1 и 2 УК); умышленное причинение тяжкого вреда здоровью, повлекшее по неосторожности смерть пострадавшего (ст. 111 ч. 4 УК); посягательство на жизнь других граждан общества. Кроме этих преступлений, к компетенции районного суда отнесены и другие особо тяжкие преступления. Поэтому появляется вопрос: почему преступления, содержащиеся в ч.2 ст.20 отнесены к суду с участием присяжных 
заседателей, а к другим особо тяжким преступлениям участие присяжных заседателей не предусмотрено.

Изучая практику работы судов с участием присяжных заседателей, можно отметить тенденцию о потребности действенного привлечения населения в деятельности судебного производства, так как это снижает риск судебных ошибок при рассмотрении самостоятельного слушания дела судьей; снижается влияние профессиональной деформированности на решение суда; присутствием общественных представителей в лице присяжных обязывает к требовательности процедуры слушания дела; при участии граждан в вынесении решении в судебном производстве увеличивает доверие населения суду.

С объективной стороны, присутствие в процессе судопроизводства присяжных заседателей способствует принятию беспристрастного и справедливого решения.

По данным Судебного департамента при Верховном суде Российской Федерации процент оправдательных приговоров снижается: «0,54\% в 2014 году, 0,43\% в 2015 году и 0,36\% в 2016 году» [9].

По данным Управления судебного департамента в Тамбовской области в 2018г.» судом присяжных Тамбовской области было рассмотрено только 1 дело и вынесен оправдательный приговор суда присяжных» [10].

Несмотря на двадцатипятилетний период своего существования, российский суд присяжных заседателей серьезного влияния на уголовную политику государства не оказал, что обусловлено изменением вектора на компромиссное, ускоренное и сокращенное правосудие. Так, ежегодно в России судом присяжных заседателей рассматривается в среднем 500-700 уголовных дел, или 0,06 \% от общего числа уголовных дел, рассмотренных судами первой инстанции. При этом наблюдается тенденция к уменьшению их количества что обусловлено, в частности, сокращением количества заявляемых обвиняемыми ходатайств из-за снижения числа выносимых оправдательных вердиктов и 
более суровых сроков наказания, если подсудимый признан виновным и не заслуживающим снисхождения.

В Токарёвском районном суде Тамбовской области слушалось судом с участием присяжных уголовное дело по обвинению совершения убийства 36летнего местного жителя.

Пострадавшим стал украинский гражданин 26-летнего возраста. При проведении следственных мероприятий в начале декабря 2018г. мужчины находились в доме своего приятеля за распитием спиртных напитков. В происшедшей ссоры один из них обвинил будущего убийцу в присвоении общих сигарет. Совершаются различные стадии конфликта. Итогом послужило получение ножевых ранений в грудь, голову, шею. Пострадавший умер от потери крови. Подсудимый свою вину в убийстве отрицал, но достаточная доказательственная база подтвердила его виновность. Данные материалы о доказанности его убийства были представлены коллегии присяжных, вынесшие все как один решение о виновности подсудимого в совершении убийства гражданина Украины.

Как комментирует старший помощник прокурора Тамбовской области Н.Истомина: «Это второе дело в нашей области, рассматриваемое в районном суде с участием присяжных заседателей. Первое уголовное дело с присяжными заседателями рассматривалось в текущем году в Котовском городском суде, где также был вынесен обвинительный вердикт [5].

Нельзя не согласиться мнением Е.А. Асеевой и О.В. Качаловой, что признание обвиняемого виновным это не только решение органа власти, но и решение такими же гражданами, как он сам, способствует повышению престижа выносимых вердиктов деятельности судов в целом» [4, с.33-40].

Повышается воспитательный результат, итог судебного слушания, присутствие присяжных заседателей показывает независимость суда.

Непредубежденный контроль, живое участие граждан в деятельности правосудия усиливают ступень демократизации общества и государства. 
Присутствие присяжных заседателей служит индивидуализации конкретного слушаемого дела.

При рассмотрении конкретного дела, вносятся мнения, характерные для современного развития общества, в правосудие привносится житейский здравый смысл. Слушание дела, это не только юридические вопросы, но и общечеловеческое содержание, присущее каждому нормальному человеку, так как правосудие только тогда будет таковым, если оно очевидно широким слоям современного общества.

Механизм принятия решений присяжными заседателями отличается от механизма принятия решения профессиональным судьей. Он не включает этапы оценки повода к принятию решения и юридической квалификации; совокупность субъективных факторов, воздействующих на принятие решения присяжными заседателями, иная, нежели для профессиональных судей, она включает в себя особенности восприятия процессуальной информации непрофессиональными участниками судопроизводства.

Иной, нежели у профессиональных судей, уровень правосознания (обыденное правосознание, отсутствие профессиональной деформации и т.д.); иные подходы к оценке полученной информации; особенности воздействия внешней среды на присяжных заседателей.

В ст.333 УПК РФ конкретизируются права присяжных заседателей:

- изучать все обстоятельства уголовного дела, через председательствующего задавать вопросы участникам судебного заседания, осматривать вещественные доказательства, документы;

- обращаться с председательствующему о разъяснении норм законодательства по рассматриваемому делу, о содержании озвученных документов и другие возникающие вопросы;

- производить собственноручные пометки по различным вопросам и правом воспользоваться ими в совещательной комнате. 
Когда образована коллегия присяжных заседателей на данном слушании дела, то председательствующий не так уж много сведений сообщает им о рассматриваемом деле.

В реальности современные присяжные заседатели приступают к судебному процессу с чистого листа. По законодательству перед судебным слушанием никакой подготовки не проводится, с материалами дела они не знакомятся, у них нет копии обвинительного заключения. В зал заседания они приходят ни с чем.

Нет никаких прав и в анализе личности обвиняемого.

В ч. 8 ст. 335 УПК РФ установлено, что сведения о личности подсудимого анализируются при участии присяжных заседателей только в той мере, в которой они нужны при определении конкретных признаков состава преступления, в котором он обвиняется. Запрещен факт обращения к прежней судимости подсудимого, нельзя касаться некоторых других его черт. Необходимо остерегаться использовать другие сведения, чтобы заранее не создать отрицательного мнения в отношении подсудимого.

Можно отметить, почему законодатель не рассматривает такие опасения в отношении председательствующего, который определяет обвиняемому меру наказания. Несостоятельность таких запретов реальна.

Ведь присяжные заседатели живут не в изолированном обществе. Многие окружающие знают, когда будет суд, в чем обвиняется гражданин, что его может ожидать и т.п. Почему бы присяжным заседателям не дать официальные сведения о подсудимом.

При таком раскладе дел можно сказать, обвиняемый в суде с участием присяжных находится в более благоприятной обстановке, чем в обычном суде. Здесь не соблюдается, в какой-мере принцип равенства, права потерпевших, индивидуальность которых может рассматриваться с разных аспектов.

Присяжные заседатели не обладают правовыми знаниями, у них часто возникают определенные вопросы по исследуемому делу, поэтому им необходимы консультации по вопросам правового законодательства. Ответы по 
возникающим вопросам они должны услышать от председательствующего (п.2 ч.1 ст.333 УПК РФ).

При этом, конечно, проблема не исчезает. Нельзя исключить такое положение дел, что председательствующий заинтересован в нужном ему исходе дела, поэтому его советы могут быть не вполне объективными.

Поэтому, присяжным заседателям можно дать право обращаться за консультациями по вопросам права к независимым экспертам. К праву предоставления присяжным вести собственноручные записи, дополнить и право возможности применения звукозаписывающей техники.

Решения присяжных заседателей порой не поддаются никакому объяснению, поскольку они не юристы и подвержены влиянию толпы, что уменьшает их ответственность за принятые решения. Отчасти с данными доводами согласиться можно, но недостатки эти вызваны особенностями суда указанной формы отправления правосудия (отсутствие юридического образования), и их устранение влечет утрату судом присяжных заседателей своей сущности. Также не вполне состоятелен довод об их склонности к вынесению необоснованных оправдательных вердиктов, так как немалая доля ответственности за это лежит и на органах уголовного преследования, неспособных представить суду качественные доказательства.

В определенной мере можно согласиться лишь с утверждением о том, что высокий процент вынесения оправдательных вердиктов обусловлен и сложностью оценки присяжными заседателями обстоятельств исследуемого события, которые бывает трудно оценить и профессиональным юристам. Особенно это актуально для ситуаций, когда по результатам расследования отсутствуют точные выводы, есть сложные формулировки в экспертных исследованиях, неточно сформулированы вопросные листы, либо стороны процесса недостаточно подготовлены к судебному разбирательству. Последнее утверждение касается государственного обвинителя, который не всегда способен доступно донести до присяжных заседателей доказательства, представленные стороной обвинения. 
При слушании уголовного дела возникает определенная проблема в истинном восприятии озвученных перед ними вопросов. По мнению О.В. Волколупа, «причины непредсказуемых вердиктов присяжных часто кроются в формулировках вопросного листа, которые по тем или иным причинам оказываются присяжным непонятными» [2, с.18-20].

На самом деле, суд присяжных может иногда беспочвенно выносить оправдательный приговор подозреваемым и этим самым дискредитировать институт присяжных.

Все слышали об уголовном деле Ульмана, Пола Хлебникова, Анны Политковской, отмененные вышестоящими инстанциями. Профессиональному суду также присуще совершать ошибки, когда уголовные дела рассматриваются вышестоящими судами ввиду нарушений закона.

Как кажется, основная причина недоверчивого отношения к решениям присяжных заседателей состоит в том, что средства массовой информации привлекают особое внимание, если отменяется решение присяжных. Но если вышестоящий суд соглашается с вердиктом присяжных, то СМИ почему-то не обращают внимание на данный вопрос и нигде его не затрагивают в своих сообщениях.

Кроме того, доводы о высоком проценте оправдательных вердиктов не следует считать обоснованными, реально их показатель ниже (в среднем 12-15 \%), поскольку количество дел, рассмотренных присяжными заседателями, меньше количества дел, рассмотренных составом суда без их участия. В среднем это три-четыре уголовных дела в год на каждый субъект Российской Федерации, и, как правило, выносится один оправдательный вердикт, тогда как в судах без их участия он выше. Если даже предположить, что присяжные заседатели выносят больше оправдательных вердиктов, причины низкого количества оправдательных приговоров без их участия объясняются высоким процентом рассмотрения дел в особом порядке (до 60 \%). Как полагает ряд авторов, это «не способствует достижению истины, повышению профессионализма государственных обвинителей и председательствующих 
судей, так как облегчает их работу в судебном разбирательстве уголовного дела» $[6$, с.41-46].

Рассматривая статистику деятельности судов с участием присяжных заседателей можно отметить такую тенденцию: с 2000 года фиксируется снижение числа обращений подозреваемых о рассмотрении их дел судом при участии присяжных. Вот некоторые причины:

Во-первых, это происходит по причине сомнения самих обвиняемых, которые не уверены, что целесообразно доверять рассмотрение своего дела непрофессиональным юристам; а также широкой практики отмены приговоров, постановленных на основании вердикта присяжных заседателей; крайне сжатых условий обжалования приговора по сравнению с обычным составом суда.

Во-вторых, все чаще обвиняемые на стадии предварительного слушания отказываются от ранее заявленных ими обращений о слушании дела судом присяжных. Это предопределено тем, что обвиняемый может быть эмоционально подвержен позиции своего защитника, который советует ему отказаться от выбранной формы судебного производства с участием присяжных заседателей, а также информированностью обвиняемого о проблемах, имеющихся при образовании коллегии присяжных.

Однако и отвергать то обстоятельство, что суд присяжных заседателей нуждается в реформировании, нельзя, так как на стадии подготовки, проведения и окончания судебного разбирательства, пересмотра принятых им решений присутствуют проблемы правового и организационного характера.

О.Т. Анкудинов считает, что при реформировании суда присяжных приходится сталкиваться с проблемами, которых не миновать. Все сталкиваются с проблемой формирования коллегии присяжных, особенно там, где малочисленное население, или где существуют конфликты между определенными группами людей. Да и где соответствующее число населения, большие проблемы возникают при составлении списков кандидатов. Уменьшение числа количества присяжных не решит эту проблему. О.Т. 
Анкудинов размышляет о вопросах, которые задаются присяжным. Он предлагает: «Правильнее задавать им только один вопрос - о виновности или невиновности, а все остальное отдать на откуп судье права» [1, с.20-23].

Новый Федеральный закон от 23 июня 2016 года № 190-Ф3 «О внесении изменений в УПК РФ об увеличении использования института присяжных заседателей» демонстрирует собой еще один шанс законодателя модернизировать нынешний суд с участием присяжных заседателей.

Организационные проблемы касаются: извещения участников процесса о времени и месте отбора и формирования коллегии присяжных, когда требуется организовать явку кандидатов в присяжные заседатели и сбор информации о них; обеспечения безопасности участников судебного разбирательства; работы суда после провозглашения вердикта уже без участия присяжных заседателей; исполнения письменных распоряжений судьи и т. д. К примеру, проблемы в обеспечении мер безопасности присяжных заседателей ведут к их неявке в судебное заседание из-за опасений за свою жизнь и здоровье.

Можно предложить следующие меры совершенствования суда присяжных:

- У присяжных заседателей должно быть право самостоятельно подготавливать и лично задавать вопросы участникам судебного заседания в ходе судебного следствия как в письменно, так и устно;

- иметь в наличии копии обвинительного заключения для большего понимания происходящего судебного процесса;

- у присяжных заседателей должно быть право о рассматривании уголовного дела в полном объеме, знакомиться с теми доказательствами, которые были признаны судом недопустимыми;

- выносить законный, обоснованный, аргументированный приговор присяжным необходимо вместе с профессиональным судьей определять лицу, который признан виновным, меру наказания. Это способствовало бы им с большим пониманием и участием следить за ходом судебного следствия по уголовному делу и выносить соответствующий вердикт.

\section{Список литературы:}


1.Анкудинов А.Т. Может, правильнее задавать присяжным только один вопрос - о виновности или невиновности? / А.Т. Анкудинов // Уголовный процесс. - 2016.- № 4. - С. 20-23.

2. Волколуп О.В., Стус Н.В. О проблемах регулирования судебного разбирательства с участием присяжных заседателей / О.В. Волколуп, Н.В. Стус // Российский судья. - 2011. - № 10. - С. 18-20.

3. Ильюхов А.А. Судебное разбирательство с участием присяжных заседателей: теоретические и правовые основы / А.А. Ильюхов //Российское право: Образование, Практика. Наука. - 2018. - №4. - С. 5-12.

4. Качалова О.В., Асеева Е.А. Формы участия граждан в осуществлении правосудия по уголовным делам / О.В. Качалова, Е.А. Асеева // Российское правосудие. - 2015. -№ 6. - С. 33-40.

5. Конейков И. Суд присяжных в Токарёвке Тамбовской области признал местного жителя виновным в убийстве / И.Конейков [Электронный ресурс].URL: $\quad$ https://www.vestitambov.ru/new/sud-prisyazhnyh-v-tokaryovke-priznalmestnogo-zhitelya-vinovnym-v-ubijstve/ (Дата обращения: 22.11.2019 г.).

6. Корчагин А. Ю. Принципы и уровни организации судебного разбирательства / А.Ю.Корчагин // Российская юстиция. - 2012. - № 8. - С.41-46.

7. О внесении изменений в Уголовно-процессуальный кодекс Российской Федерации в связи с расширением применения института присяжных заседателей. Федеральный закон от 23.06.2016 № 190-Ф3 // Собрание законодательства РФ. - 2016. - № 26 (Часть I). -Ст. 3859.

8. Русская правда в краткой редакции [Электронный ресурс].- URL: http://www.hrono. ru/dokum/ 1000dok/pravda72.php (Дата обращения 30.11.2019г.).

9. Судебный департамент при Верховном суде РФ [Электронный ресурс].. URL http: //www.cdep.ru (Дата обращения 15.11.2019г.).

10. Оперативная отчетность Управления судебного департамента Тамбовской области за 2018г. [Электронный ресурс]. - URL: http://usd.tmb.sudrf.ru (Дата обращения: 15.11.2019г.). 